\title{
Antioxidative capacities of some GABAA receptor modulating food plants
}

\author{
Sümeyye ŞAHIN $D^{1}$ \\ ${ }^{1}$ Department of Food Engineering, Faculty of Agriculture, Ordu University, Ordu, Turkey \\ Alınış tarihi: 6 Ağustos 2019, Kabul tarihi: 13 Aralık 2019 \\ Sorumlu yazar: Sümeyye ŞAHIN, e-posta: sumeyyesahin@odu.edu.tr
}

\begin{abstract}
Reactive oxygen species cause oxidative stress associated with some health issues such as neurodegenerative diseases. Some antioxidants show neuroprotective activity and regulate neuronal activity through positive modulation of $\mathrm{GABA}_{\mathrm{A}}$ receptors. In this study, the antioxidative capacity of some novel $\mathrm{GABA}_{\mathrm{A}}$ receptor modulating food plants, including lavender, clove and four Sideritis species (S. arguta, S. sipylea, S. condensata, and S. stricta) was investigated using ABTS assay. The aqueous clove extract showed the most potent antioxidant effect and its $\mathrm{IC}_{50}$ value was found to be $3.76 \mu \mathrm{g} / \mathrm{mL}$. The antioxidant capacity of Trolox was lower ( $\mathrm{IC}_{50}: 4.63$ $\mu \mathrm{g} / \mathrm{mL}$ ) than that of the clove extract, but higher than those of the other food extracts. The aqueous lavender extract exhibited less antioxidant activity compared to Sideritis species, except S. sipylea that had the least antioxidant capacity ( $\mathrm{IC}_{50}$ : 20.75 $\mu \mathrm{g} / \mathrm{mL}$ ). In conclusion, these results confirm that $\mathrm{GABA}_{\mathrm{A}}$ receptor modulating food plants possess strong antioxidative activity.
\end{abstract}

Key words: Sideritis, lavender, clove, antioxidative capacity

\section{Bazı GABA $A_{A}$-reseptör modüle edici bitkisel gidaların antioksidant kapasiteleri}

Öz

Reaktif oksijenler nörodejeneratif hastalıklar gibi bazı sağlık sorunlarına yol açan oksidatif strese neden olurlar. Bazı antioksidanlar nöroprotektif aktivite gösterir ve $\mathrm{GABA}_{\mathrm{A}}$ reseptörlerinin pozitif modülasyonu ile nöronal aktiviteyi düzenlerler. $\mathrm{Bu}$ çalışmada bazı yeni $\mathrm{GABA}_{A}$ reseptör modüle edici bitkisel gidalardan lavanta, karanfil ve 4 Sideritis türünün ( $S$. arguta, $S$. sipylea, $S$. condensata, ve $S$. stricta) ABTS metodu ile antioksidant etkileri araştırılmıștır. Karanfilin sulu ekstraktı en yüksek antioksidant etki göstermiştir ve $\mathrm{IC}_{50}$ değeri 3.76 $\mu \mathrm{g} / \mathrm{mL}$ olarak bulunmuştur. Trolox'un antioksidant kapasitesi (IC ${ }_{50}: 4.63 \mu \mathrm{g} / \mathrm{mL}$ ) karanfilden düşük ancak diğer bitki ekstraktlarından yüksek bulunmuştur. Sulu lavanta ekstraktı, S. sipylea hariç diğer Sideritis türleri ile karşılaştırıldığında en düşük antioksidant kapasitesi göstermiştir (IC ${ }_{50}: 20.75$ $\mu \mathrm{g} / \mathrm{mL}$ ). Sonuç olarak, bu deney sonuçları $\mathrm{GABA}_{A}$ reseptör module edici bitkisel gıdaların güçlü antioksidant etkiye de sahip oldukların doğrulamaktadır.

Anahtar kelimeler: Sideritis, lavanta, karanfil, antioksidant kapasite

\section{Introduction}

Increase in the reactive oxygen species in the cell causes DNA damage, oxidation of proteins, and lipid degradation (Sesti et al., 2010). Therefore, some chronic and acute diseases, including cardiovascular diseases, cancer, and neurodegenerative diseases, are associated with oxidative stress (Willcox et al., 2004). It has been shown that several antioxidantse.g. phenolic compounds have neuroprotective effects (Reiter, 1998; Ha et al., 2000; Zbarsky et al., 2005; Silva et al., 2009; Wu et al., 2014). Furthermore, some antioxidants exhibit not only neuroprotective effect but also modulation of the neuronal activity via $\mathrm{GABA}_{\mathrm{A}}$ receptors (Ha et al., 2000; Silva et al., 2009; Wu et al., 2014), which are activated by GABA ( $\gamma$-aminobutyric acid). Physiologically important amino acid GABA is a major neurotransmitter in the brain so that $40 \%$ of 
all neurons in the mammalian central nervous system are GABAergic neurons (Granger et al., 2005). $\mathrm{GABA}_{\mathrm{A}}$-receptors are targets for various groups of medications including sedatives, anxiolytics, muscle relaxants, antidepressants and antiepileptics (Möhler, 2006; Sigel and Steinmann, 2012). Some foods and food components which have the antioxidant, antiepileptic, sedative, antidepressant, anxiolytic, or calming effect can modulate GABAA-receptors (Kessler et al., 2012; Kessler et al., 2014; Sahin et al., 2016; Sahin et al., 2017; Silva et al., 2015). For example, it has been reported that lavender had antioxidant activity and exhibited the sleep-inducing, anxiolytic and sedative activity linked to its modulatory effect on $\mathrm{GABA}_{\mathrm{A}}$ receptors (Alnamer et al., 2012; Aoshima and Hamamoto, 1999; Kessler et al., 2012; Sahin et al., 2016; Shaw et al., 2007; Silva et al., 2015; Woronuk et al., 2011). Some Sideritis species demonstrated antioxidant, analgesic and anticonvulsant effects (Charami et al. 2008; Hernandez-Perez et al., 2004; Gonzalez-Burgos et al., 2011) and enhanced the activity of $\mathrm{GABA}_{\mathrm{A}}$-receptors in different cell expression systems (Kessler et al., 2012; Sahin et al., 2016). The clove (Syzygium aromaticum L.) acting as antioxidant exhibited topical anesthetic, analgesic, antiepileptic, and anxiolytic effects (Alqareer et al., 2006; Carlsen et al., 2010; Gülçin et al., 2004; Halder et al., 2012; Hosseini et al., 2011) which could be partially mediated by positive modulation of the $\mathrm{GABA}_{\mathrm{A}}$ receptor (Sahin et al., 2017). Recently, these three plants -lavender, clove, and some of the Sideritis species- have been identified as specific positive modulators for the $\mathrm{GABA}_{\mathrm{A}}$ receptors (Sahin et al., 2016; Sahin et al., 2017). Since several antioxidants with neuroprotective properties, also exhibit neurophysiological effect through $\mathrm{GABA}_{\mathrm{A}}$ receptors, the aim of this study was to determine the antioxidative capacity of novel $\mathrm{GABA}_{\mathrm{A}}$ receptor modulating food plants; lavender, clove and four Sideritis species (S. arguta, S. sipylea, S. condensata, and $S$. stricta).

\section{Materials and Methods}

\section{Chemicals}

Trolox ( \pm ) 6-hydroxy-2,5,7,8-tetramethylchromane2-carboxylic acid), ABTS, potassium persulfate, sodium dihydrogen phosphate dihydrate $\left(\mathrm{H}_{2} \mathrm{NaO}_{4} \mathrm{Px}\right.$ $2 \mathrm{H}_{2} \mathrm{O}$ ), and disodium hydrogen phosphate dihydrate $\left(\mathrm{HNa}_{2} \mathrm{O}_{4} \mathrm{P} \times 2 \mathrm{H}_{2} \mathrm{O}\right)$ were purchased from SigmaAldrich (Taufkirchen, Germany).

\section{Plant material and preparation of extracts}

The three Sideritis species (S. arguta, S. condensata, and $S$. stricta) were obtained from Akdeniz University, Antalya, Turkey while $S$. sipylea was supplied from an online store (enexia.de). Clove buds (Syzygium aromaticum L., Hallesche Essig- und Senffabrik, Bad Dürrenberg, Germany) were purchased from a local supermarket. Lavender flowers (Lavendula officinalis) were obtained in crushed form from a local pharmacy. The identity of these plants was verified as described before (Sahin et al., 2016). The Sideritis species and clove buds were coarsely ground before extraction, whereas the crushed lavender flowers were used directly. Each test material was mixed with boiling water $(2.5$ $\mathrm{g}: 100 \mathrm{~mL}$ ). After stirring for $15 \mathrm{~min}$ at room temperature, the mixtures were filtered using Whatman filter paper and the filtrates were lyophilized. The lyophilized samples were dissolved in water $(1 \mathrm{mg} / \mathrm{mL})$ prior to experiments. Extraction was repeated two times.

\section{ABTS assay for antioxidant activity evaluation}

Antioxidative capacity was measured using the ABTS-radical assay according to literature Lee et al. (2015) with some modifications. The ABTS in water (7 mM) was mixed with $2.45 \mathrm{mM}$ of potassium persulfate to prepare the ABTS reagent. 1-20 $\mu \mathrm{L}$ of the plant extracts were added to $180-199 \mu \mathrm{L}$ of ABTS reagent in a 96-well microplate. After incubation at room temperature for $6 \mathrm{~min}$, the absorbance was measured at $734 \mathrm{~nm}$ using a microplate spectrophotometer ( $\mu$ Quant BioTek). The Trolox was used as the antioxidant standard and dissolved in 75 $\mathrm{mM}$ of potassium phosphate buffer ( $\mathrm{pH} 7.4$ ). All the samples were analyzed in triplicates. The absorbance of the ABTS reagent without the addition of sample was used as the control. Percent inhibition of absorbance was calculated using the following equation: ABTS scavenging effect $(\%)=\left(\left(\mathrm{A}_{\text {control }}-\right.\right.$ Asample)/ $\left.A_{\text {control }}\right)$ x100, where "A" represents absorbance.

\section{Data analysis}

Linear regression was performed to determine the $\mathrm{IC}_{50}$ values (the half-maximal inhibitory concentration) of the extracts $( \pm 95 \%$ confidence interval [CI]) using OriginPro 2018b (OriginLab Corporation, Northampton, MA 01060 USA). Statistical data analysis was done by Minitab (version 18.1) using one-way ANOVA. Following ANOVA, the Tukey multiple comparisons test was performed with significance levels $\mathrm{p}<0.05$. 


\section{Results and Discussion}

The present study evaluated the antioxidative activity of some GABAergic food plants (four Sideritis spp., clove, and lavender) using ABTS radical assay based on the measurement of the reduction in the radical cation as the percentage of inhibition in the absorbance at $734 \mathrm{~nm}$. The Trolox was used at the concentrations of $0.94,1.88,2.82,3.75$, and 4.69 $\mu \mathrm{g} / \mathrm{mL}$ to obtain a Trolox dose-response curve (Fig. 1).

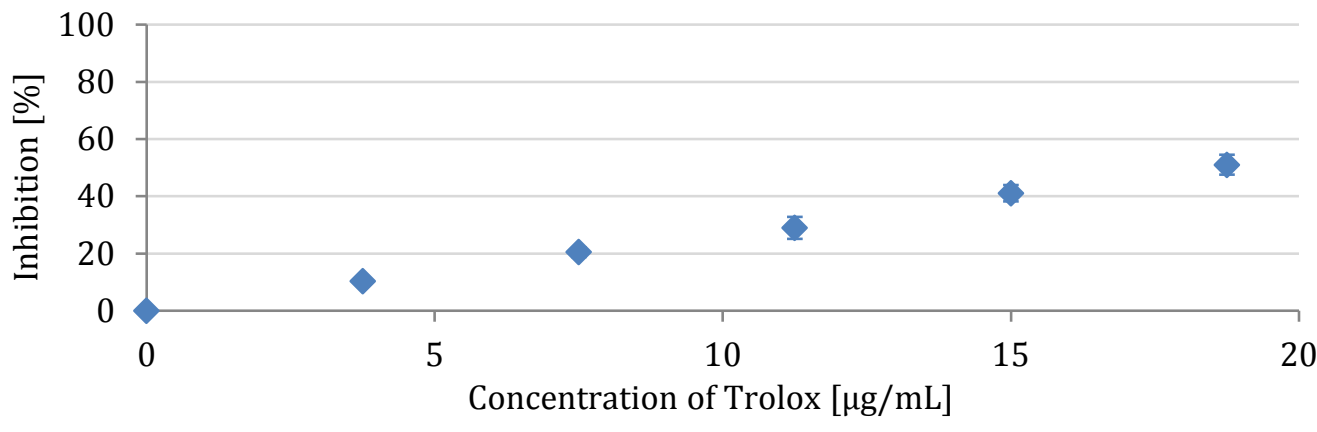

Figure 1. ABTS radical-scavenging activities of Trolox. The results are means of three different experiments, in each of which three measurements were made.
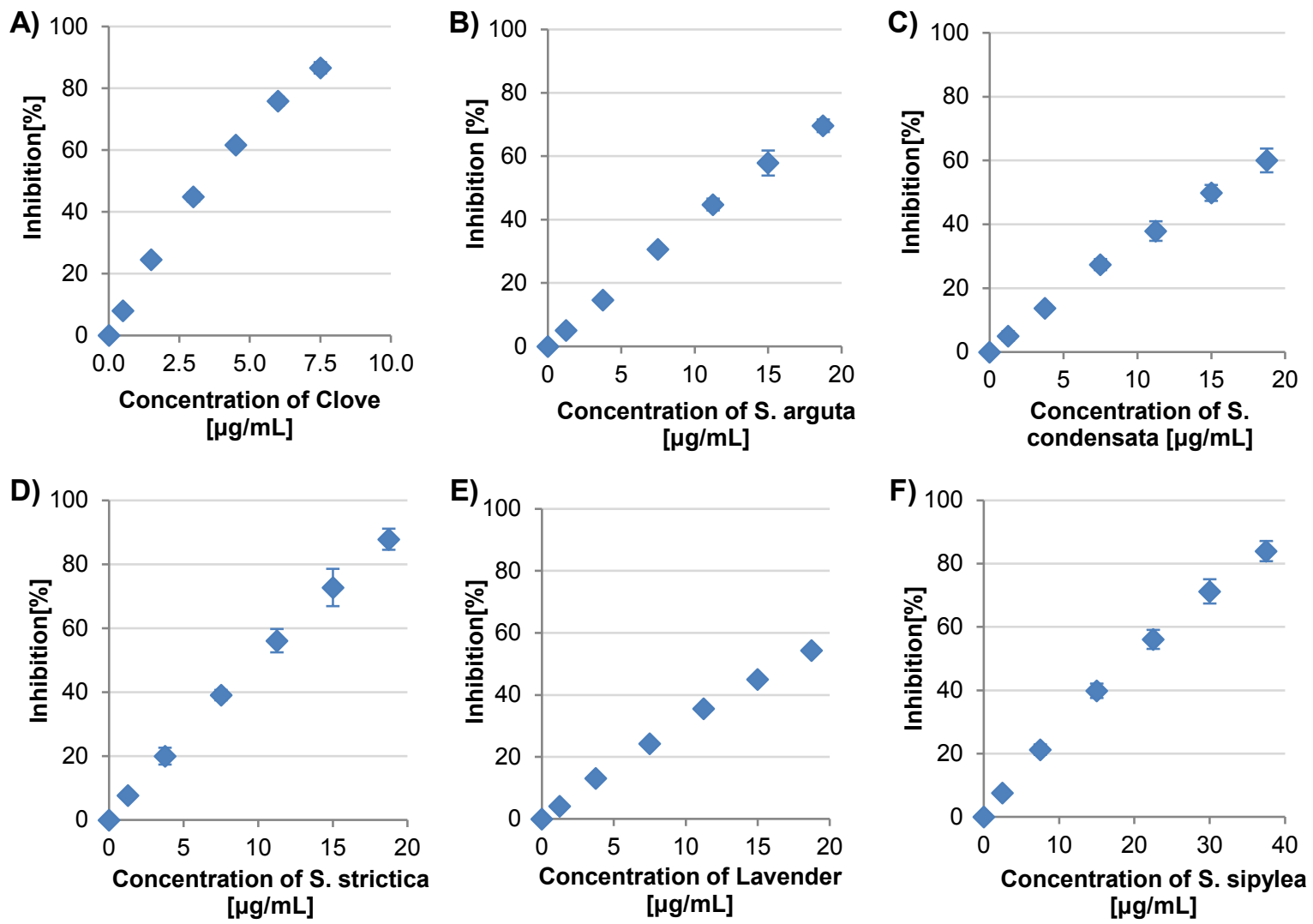

Figure 2. ABTS radical-scavenging activities of the aqueous plant extracts; A) Clove, B) $S$. arguta, C) $S$. condensata, D) S. strictica, E) Lavender, F) S. sipylea.

Each food extract was tested at various concentrations $(0.5-37.5 \mu \mathrm{g} / \mathrm{mL})$ and their inhibitory effect was assessed by determining $\mathrm{IC}_{50}$ values (50\% inhibitory concentration). Similar to the Trolox, all tested plant extracts exhibited a radical scavenging activity in a dose-dependent manner (Fig. 2).

The aqueous extract of clove buds had the highest antioxidant activity with an $\mathrm{IC}_{50}$ value of $3.76 \mu \mathrm{g} / \mathrm{mL}$. To achieve fifty percent inhibition, the required concentration of Trolox $(4.63 \mu \mathrm{g} / \mathrm{mL})$ was higher 
than that of aqueous clove extract but lower than that of the other aqueous food extracts (Table 1). When tested at $7.5 \mu \mathrm{g} / \mathrm{mL}$, the clove extract inhibited ABTS cation formation by $86.6 \%$, whereas the other food extracts caused approximately 20-40 \% inhibition of oxidation of ABTS. Among Sideritis species, $S$. stricta was the most active, followed by $S$. arguta and $S$. condensata. The $\mathrm{IC}_{50}$ value of $S$. stricta was 2.7-fold higher than $\mathrm{IC}_{50}$ value of the clove extract. All the tested Sideritis species were more potent inhibitors compared to lavender extract, except $S$. sipylea which showed the lowest antioxidant activity with the $\mathrm{IC}_{50}$ value of 20.75 $\mu \mathrm{g} / \mathrm{mL}$ (Table 1).

Table 1. IC 50 of samples

\begin{tabular}{|c|c|}
\hline Samples & $\mathrm{IC}_{50}$ (with $95 \%$ confidence interval) $[\mu \mathrm{g} / \mathrm{mL}]$ \\
\hline Clove & $3.76(3.33-4.19)^{\mathrm{C}}$ \\
\hline Trolox & $4.63(4.17-5.10)^{\mathrm{C}}$ \\
\hline S.stricta & $10.16(9.10-11.21)^{\mathrm{BC}}$ \\
\hline S.arguta & $12.70(11.41-13.99)^{\mathrm{B}}$ \\
\hline S.condensata & $14.99(13.44-16.54)^{\mathrm{AB}}$ \\
\hline Lavender & $16.81(15.04-18.57)^{А В}$ \\
\hline S. sipylea & $20.75(18.57-22.94)^{A}$ \\
\hline
\end{tabular}

A-C The values indicated by the different letters differ from each other significantly by the Tukey test $(\mathrm{p}<0.05)$.

Güvenç et al. (2008) tested the aqueous extracts of the 17 lyophilized (50 g plant: $600 \mathrm{~mL}$ water) Sideritis species including $S$. arguta, $S$. condensata, and $S$. sipylea for their antioxidant activities. They used two methods (DPPH and Thiobarbituric acid assays) to evaluate the antioxidative capacity. They reported that S. arguta, S. condensata, and S. sipylea showed strong antioxidant activities although they only observed the color change under UV light but lacked the absorbance measurements in the DPPH assay. In Thiobarbituric acid (TBA) test, $S$. sipylea exhibited a low antioxidant activity (IC $50: 0.71 \pm 0.05$ $\mathrm{mg} / \mathrm{mL}$ ) as compared with the other two Sideritis species (IC 50 value of $S$. arguta: $0.44 \pm 0.23 \mathrm{mg} / \mathrm{mL}$ and $\mathrm{IC}_{50}$ value of $S$. condensata: $0.33 \pm 0.04 \mathrm{mg} / \mathrm{mL}$ ) (Güvenç et al., 2008). This result also supports our current findings where $S$. sipylea was the least potent among tested four Sideritis species including $S$. arguta and $S$. condensata.

Lavender (Lavendula officinalis), similar to the genus Sideritis, belongs to the Labiateae family and is commonly used for its sleep-inducing, sedative and calming effects (Woronuk et al., 2011). Lavender owes its GABAergic effect to the positive modulation of GABAA receptors (Kessler et al., 2012; Sahin et al., 2016). The present findings demonstrated that the antioxidant activity of aqueous extract of lavender was lower compared to the aqueous extract of clove buds. Similarly, Gülçin et al. (2004) reported that not only the aqueous extract but also the ethanolic extract of lavender had less antioxidant activity than the aqueous and ethanolic extract of clove buds based on the DPPH assay (Gülçin et al., 2004).

Clove (Syzygium aromaticum L.) belongs to the Myrtaceae family, and its essential oil is used in dental care due to its anesthetic and analgesic effects (Alqareer et al., 2006; Hosseini et al., 2011; Halder et al., 2012). Among tested GABAergic food plants in the present study, it was observed that the aqueous clove bud extract exhibited the most potent antioxidant activity and its activity was higher than the Trolox, which is a water-soluble analogue of $\alpha$ tocopherol. Both water and ethanol extracts from clove buds showed higher antioxidative capacities than $\alpha$-tocopherol in thiocyanate and DPPH methods (Gülçin et al., 2004). Using the FRAP assay, it was reported that clove had the highest antioxidant capacity among 3139 different foods tested including beverages, spices, herbs, and supplements (Carlsen et al., 2010). Additionally, the antioxidative capacity of clove buds was compared with the most commonly used antioxidants the butylated hydroxyanisole (BHA) and butylated hydroxytoluene (BHT). The ethanolic extract of clove had stronger DPPH radical scavenging activity compared to the synthetic chemicals BHA and BHT at the concentration of $60 \mu \mathrm{g} / \mathrm{mL}$, whereas the activity of its aqueous extract was higher than BHT but similar to BHA (Gülçin et al., 2004). Previously, eugenol was detected in the aqueous clove extract by UHPLCDAD and GC-MS analysis and identified as the main clove component predominantly responsible for $\mathrm{GABA}_{\mathrm{A}}$ receptor modulation (Sahin et al., 2017). It was shown that eugenol was a strong antioxidant, so that its low concentration $(15 \mu \mathrm{g} / \mathrm{mL})$ had higher antioxidative capacity than BHA, Trolox, and $\alpha$ tocopherol (Gulcin, 2011).

\section{Conclusion}

The results of the present study demonstrate that novel GABAA receptor modulating food plants (lavender, clove, and four Sideritis species -S. arguta, S. sipylea, $S$. condensata, and S. stricta-) possess strong antioxidant potential at low concentrations. The clove, lavender and Sideritis species may offer a potential for developing new therapeutic agents which can be used to treat neurological disorders. 


\section{Acknowledgments}

I would like to thank Monika Pischetsrieder, Friedrich Alexander University (FAU), for supplying plant samples and chemicals.

\section{References}

Alnamer, R., Alaoui, K., Bouidida el, H., Benjouad, A., Cherrah, Y., 2012. Sedative and Hypnotic Activities of the Methanolic and Aqueous Extracts of Lavandula officinalis from Morocco. Advances in Pharmacological Sciences, 2012: 270824.

Alqareer, A., Alyahya, A., Andersson, L., 2006. The effect of clove and benzocaine versus placebo as topical anesthetics. Journal of Dentistry, 34(10): 747-750.

Aoshima, H., Hamamoto, K., 1999. Potentiation of GABA Receptors Expressed in Xenopus Oocytes by Perfume and Phytoncid. Bioscience, Biotechnology, and Biochemistry, 63(4): 743-748.

Carlsen, M. H., Halvorsen, B. L., Holte, K., Bøhn, S. K., Dragland, S., Sampson, L., Willey, C., Senoo, H., Umezono, Y., Sanada, C., Barikmo, I., Berhe, N., Willett, W. C., Phillips, K. M., Jacobs, D. R., Blomhoff, R., 2010. The total antioxidant content of more than 3100 foods, beverages, spices, herbs and supplements used worldwide. Nutrition Journal, 9: 3.

Charimi, M. T., Lazari, D., Karioti, A., Skaltsa, H., Hadjipavlou-Litina, D., Souleles, C., 2008. Antioxidant and antiinflammatory activities of Sideritis perfoliata subsp. perfoliata (Lamiaceae). Phytotherapy Research, 22(4):450-454.

Gonzalez-Burgos, E., Carretero, M. E., Gomez-Serranillos, M. P., 2011. Sideritis spp.: Uses, chemical composition and pharmacological activities - A review. Journal of Ethnopharmacology, 135 (2): 209-225.

Granger, R. E., Campbell, E. L., Johnston, G. A. R., 2005. (+)And (-)-borneol: efficacious positive modulators of GABA action at human recombinant a1b2g2L $\mathrm{GABA}_{\mathrm{A}}$ receptors. Biochemical Pharmacology, 69(7): 1101-1111.

Gulcin, I., 2011. Antioxidant activity of eugenol: a structure-activity relationship study. Journal of Medicinal Food, 14(9): 975-985.

Gülçin, İ., Şat, G., Beydemir, Ş., Elmastaş, M., Küfrevioğlu, Ö. İ., 2004. Comparison of antioxidant activity of clove (Eugenia caryophylata Thunb) buds and lavender (Lavandula stoechas L.). Food Chemistry, 87(3): 393-400.

Güvenç, A., Houghton, P.J., Duman, H., Coşkun, M., Şahin, P., 2008. Antioxidant activity studies on selected
Sideritis species Native to Turkey. Pharmaceutical Biology, 43(2): 173-177.

Ha J. H., L. D. U., Lee J. T., Kim J. S., Yong C. S., Kim J. A., Ha J. S., Huh K., 2000. 4-Hydroxybenzaldehyde from Gastrodia elata B1. is active in the antioxidation and GABAergic neuromodulation of the rat brain. Journal of Ethnopharmacology, 73(1-2): 329-333.

Halder, S., Mehta, A. K., Mediratta, P. K., Sharma, K. K., 2012. Acute effect of essential oil of Eugenia caryophyllata on cognition and pain in mice. Naunyn-Schmiedeberg's Archives of Pharmacology, 385: 587-593.

Hernandez-Perez, M., Sanchez-Mateo, C. C., MontalbettiMoreno, Y., Rabanal, R. M., 2004. Studies on the analgesic and anti-inflammatory effects of Sideritis candicans Ait. var. eriocephala Webb aerial part. Journal of Ethnopharmacology, 93(2-3): 279-284.

Hosseini, M., Kamkar-Asl, M., Rakhshandeh, H., 2011. Analgesic effect of clove essential oil in mice. Avicenna Journal of Phytomedicine, 1(1): 1-6.

Kessler, A., Sahin-Nadeem, H., Lummis, S. C., Weigel, I., Pischetsrieder, M., Buettner, A., Villmann, C., 2014. $\mathrm{GABA}_{\mathrm{A}}$ receptor modulation by terpenoids from Sideritis extracts. Molecular Nutrition \& Food Research, 58(4): 851-862.

Kessler, A., Villmann, C., Sahin-Nadeem, H., Pischetsrieder,

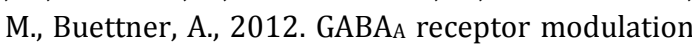
by the volatile fractions of Sideritis species used as 'Greek' or 'Turkish' mountain tea. Flavour and Fragrance Journal, 27(4): 297-303.

Lee, K. J., Oh, Y. C., Cho, W. K., Ma, J. Y., 2015. Antioxidant and anti-inflammatory activity determination of one hundred kinds of pure chemical compounds using offline and online screening HPLC assay. Evidence-Based Complementary and Alternative Medicine, 2015: 165457

Möhler, H., 2006. GABA receptors in central nervous system disease: anxiety, epilepsy, and insomnia. Journal of Receptors and Signal Transduction, 26(5-6): 731-740

Reiter, R. J., 1998. Oxidative damage in the central nervous system: protection by melatonin. Progress in Neurobiology, 56(3): 359-384.

Sahin, S., Eulenburg, V., Heinlein, A., Villmann, C., Pischetsrieder, M., 2017. Identification of eugenol as the major determinant of GABA A -receptor activation by aqueous Syzygium aromaticum L. (clove buds) extract. Journal of Functional Foods, 37: 641-649.

Sahin, S., Eulenburg, V., Kreis, W. Villmann, C., Pischetsrieder, M., 2016. Three-Step Test System for the Identification of Novel GABAA Receptor 
Modulating Food Plants. Plant Foods for Human Nutrition, 71(4): 355-360.

Sesti, F., Liu, S., Cai, S. Q., 2010. Oxidation of potassium channels by ROS: a general mechanism of aging and neurodegeneration? Trends in Cell Biology, 20(1): 45-51.

Shaw, D., Annett, J. M., Doherty, B., Leslie, J. C., 2007. Anxiolytic effects of lavender oil inhalation on open-field behaviour in rats. Phytomedicine, 14(9): 613-620.

Sigel, E., Steinmann, M. E., 2012. Structure, function, and modulation of $\mathrm{GABA}_{\mathrm{A}}$ receptors. Journal of Biological Chemistry, 287(48): 40224-40231.

Silva, M. I., Silva, M. A., de Aquino Neto, M. R., Moura, B. A., Sousa, H. L., de Lavor, E. P. H., de Vasconcelos, P. F., Macêdo, D. S., de Sousa, D. P., Vasconcelos, S. M., de Sousa, F. C., 2009. Effects of isopulegol on pentylenetetrazol-induced convulsions in mice: possible involvement of GABAergic system and antioxidant activity. Fitoterapia, 80(8): 506-513.

Silva, G. L., Luft, C., Lunardelli, A., Amaral, R. H., Melo, D. A., Donadio, M. V., Nunes, F.B., de Azambuja, M. S.,
Santana, J. C., Moraes, C. M., Mello, R. O., Cassel, E., Pereira, M. A., de Oliveira, J. R., 2015. Antioxidant, analgesic and anti-inflammatory effects of lavender essential oil. Anais da Academia Brasileira de Ciências, 87(2):1397-1408

Willcox, J. K., Ash, S. L., Catignani, G. L., 2004. Antioxidants and prevention of chronic disease. Critical Reviews in Food Science and Nutrition, 44(4): 275-295.

Woronuk, G., Demissie, Z., Rheault, M., Mahmoud, S., 2011. Biosynthesis and therapeutic properties of Lavandula essential oil constituents. Planta Medica, 77(1): 7-15.

Wu, C., Gopal, K. V., Moore, E. J., Gross, G. V., 2014. Antioxidants L-carnitine and D-methionine modulate neuronal activity through GABAergic inhibition. Journal of Neural Transmission, 121(7): 683-693.

Zbarsky, V., Datla, K. P., Parkar, S., Rai, D. K., Aruoma, O. I., Dexter, D. T., 2005. Neuroprotective properties of the natural phenolic antioxidants curcumin and naringenin but not quercetin and fisetin in a 6OHDA model of Parkinson's disease. Free Radical Research, 39(10): 1119-1125. 